\title{
Clinicohematological Profile of Anemia in Pediatric (Newborn to Eighteen Years) Age Group
}

\author{
Parin Upadhyay $^{1}$, Sujata R Kanetkar ${ }^{2}$ \\ ${ }^{1}$ Tutor, ${ }^{2}$ Professor \& Head, \\ Department of Pathology, KIMS Deemed to be University, Karad. \\ Corresponding Author: Parin Upadhyay
}

DOI: https://doi.org/10.52403/ijhsr.20220236

\begin{abstract}
Introduction: Anemia is worldwide public health issue of substantial importance. It is an ancient disease, and commonest multifactorial ailment of mankind seen all over the world. Early diagnosis of anemia in pediatric age allows to prevent its complications specially in a growing period and helps to guide further management. ${ }^{1}$

Aim: To study the clinicohematological profile of anemia in pediatric (newborn to eighteen years) age group at tertiary care centre.

Objectives:

- To study occurrence of anemias in pediatric (newborn to eighteen years) age group and classify these morphologically.

- To study etiology of anemia in pediatric (newborn to eighteen years) age group with clinicohematological correlation

Material \& Methods: Present study was conducted in the Department of Pathology at Krishna Medical Research Center on blood samples received from 176 patients with anemia in the age group of newborn to eighteen years. Hematological (CBC, Peripheral smear, Reticulocyte count, Bone marrow aspiration, HPLC) and biochemical (Serum ferritin, Serum iron, TIBC, Vitamin B12) investigations were done. Data so collected was tabulated in an excel sheet and was analysed.

Results: 110 (62.5\%) males had anemia while 66 cases (37.5\%) were females. Maximum 54 cases (30.68\%) were found within the age group of 1-5 years. Maximum 78 cases (48.32\%) of moderate degree of anemia were present. Microcytic Hypochromic anemia with 84 cases $(47.73 \%)$ was the most common morphological type. Iron deficiency anemia was more prevalent with 63 cases (35.79\%) followed by anemia of chronic inflammation/infection with 49 cases (27.84\%). Weakness, easy fatiguability, irritability were the most common symptoms presented by 145 cases $(82.39 \%)$. Pallor was the commonest sign observed in 176 cases (100\%).

Conclusion: Hematological and Biochemical investigations can be used for early diagnosis of anemia. Which allows timely initiation of optimal and appropriate therapy which can prevent further complications of anemia. Preventive programme for control of anemia in pediatric age group should be made accompanied by measures of providing appropriate nutritional requirements.
\end{abstract}

Keywords: Anemia, Pediatric age group, CBC.

\section{INTRODUCTION}

Anemia is more in pediatric age group because of ${ }^{2,3}$

I) The rapid growth in infancy when the requirement of nutrition are much more, II) High susceptibility to infection due to lack of immunity and malnourishment which produces adverse effect on hemopoiesis, III) The lack of compensatory adjustment of hemopoiesis as per demand because of poor storage of hemopoietic factors, IV) Genetically inherited anemias 
also manifest in infancy and childhood when there severity is significant.

In India, about 89 million children are anemic. Prevalence of anemias is $70 \%$ in children aged 6-59 months. ${ }^{4}$ According to National family health survey (NFHS-4) data, prevalence among children less than five years of was reported to be $58.6 \% .^{5}$

Nutritional anemias in developing countries like India constitute a significant public health problem because of prevailing socioeconomic inadequacy, poor dietary habits and high incidence of malnutrition, and parasitic infestations. As much as $51 \%$ children in 0-4 years and $46 \%$ children $5-12$ years are anemic in developing region. ${ }^{6,7}$

\section{MATERIALS \& METHODS}

Present study was conducted in the Department of Pathology at Krishna
Medical Research Centre, Karad. It was a 18 months cross sectional study on 176 patients from a period of January 2020 to June 2021. The participants of the present study were the children who were admitted in the pediatric ward with anemia during the study period. Criteria to define anemia for age group are as follows.

$\begin{aligned} & \text { Criteria to define anemia as per age } \\
& \text { group: } 8,9,10\end{aligned}$
\begin{tabular}{|l|l|}
\hline Age Group & Hemoglobin (gm/dl) \\
\hline Birth - 2 Days & $<15.0$ \\
\hline 2- 7 Days & $<14.0$ \\
\hline 1 week-2 Months & $<12.0$ \\
\hline 3 -6 Months & $<10.4$ \\
\hline 6 Months - 5 Years & $<11.0$ \\
\hline 5-11 Years & $<11.5$ \\
\hline 12-14 Years & $<12.0$ \\
\hline >14 Years (Female) & $<12.0$ \\
\hline$>14$ Years (Male) & $<13.0$ \\
\hline
\end{tabular}

Criteria used for diagnosing anemia:- WHO criteria for anemia and Grade of severity?

\begin{tabular}{|l|l|l|l|l|}
\hline & \multicolumn{1}{|c|}{ Population } & \multicolumn{3}{l|}{ Anemia $\mathbf{( g m / d I )}$} \\
\hline & \multicolumn{1}{|l|}{ Mild } & Moderate & Severe \\
\hline 1 & Children 6-59 months of age & $10.0-10.9$ & $7.0-9.9$ & $<7.0$ \\
\hline 2 & Children 5-11 years of age & $11.0-11.4$ & $8.0-10.9$ & $<8.0$ \\
\hline 3 & Children 12-14 years of age & $11.0-11.9$ & $8.0-10.9$ & $<8.0$ \\
\hline 4 & $\begin{array}{l}\text { Female } \\
\text { (14years of age and above) }\end{array}$ & $11.0-11.9$ & $8.0-10.9$ & $<8.0$ \\
\hline 5 & $\begin{array}{l}\text { Male } \\
\text { (14 years of age and above) }\end{array}$ & $11.0-12.9$ & $8.0-10.9$ & $<8.0$ \\
\hline
\end{tabular}

Cases were selected according to the following inclusion and exclusion criteria.

\section{Inclusion criteria:}

- All the IPD patients having anemia in new born to eighteen years age group from pediatric ward during the study period of 18 months from January 2020 - May 2021were included.

\section{Exclusion criteria:}

- All the pediatric patients in new born to eighteen years of age group without anemia.
- Cases having hematolymphoid malignancy were excluded.

\section{RESULTS}

The present study included 176 cases $(100 \%)$, of which 110 cases $(62.5 \%)$ were male and 66 cases $(37.5 \%)$ were females. Most common age group affected was 1-5 years of age group with maximum 54 cases $(30.68 \%)$. (Table- 1$)$.

TABLE NO 1: DISTRIBUTION OF TOTAL 176 CASES OF ANEMIA ACCORDING TO AGE \& SEX:

\begin{tabular}{|l|l|l|l|l|l|}
\hline Sr.No. & Age Group ( Years) & Male & Female & Total & Percentage (\%) \\
\hline 1. & 0-1 Years & 25 & 15 & 40 & $22.73 \%$ \\
\hline 2. & 1-5 Years & 34 & 20 & 54 & $30.68 \%$ \\
\hline 3. & 5-8 Years & 14 & 08 & 22 & $12.50 \%$ \\
\hline 4. & 8-13 Years & 22 & 10 & 32 & $18.18 \%$ \\
\hline 5. & 13-18 Years & 15 & 13 & 28 & $15.91 \%$ \\
\hline & Total & 110 & 66 & 176 & $100 \%$ \\
\hline
\end{tabular}


Parin Upadhyay et.al. Clinicohematological profile of anemia in pediatric (newborn to eighteen years) age group.

Maximum number of 78 cases (44.32\%) were of Moderate degree of anemia. (Table-2)

TABLE.NO 2: DISTRIBUTION OF CASES ACCORDING TO SEVERITY OF ANEMIA IN 176 CASES:

\begin{tabular}{|l|l|l|l|}
\hline Age Group (Years) & Mild & Moderate & Severe \\
\hline 0-1 Years & 12 & 19 & 9 \\
\hline 1-5 Years & 7 & 28 & 19 \\
\hline 5-8 Years & 5 & 9 & 8 \\
\hline 8-13 Years & 9 & 13 & 10 \\
\hline 13-18 Years & 5 & 9 & 14 \\
\hline Total & 38 & 78 & 60 \\
\hline Percentage $(\%)$ & $21.59 \%$ & $44.32 \%$ & $34.09 \%$ \\
\hline
\end{tabular}

\section{Microcytic}

Hypochromic,

Normocytic Normochromic anemia, Normocytic hypochromic anemia, Macrocytic Hypochromic anemia \&
Macrocytic Normochromic anemia, were reported in $47.73 \%, 21.59 \%, 13.07 \%$, $10.79 \% \& 6.82 \%$ respectively. (Table- 3 )

Iron deficiency anemia was the commonest nutritional deficiency anemia seen in 63 cases $(35.79 \%)$. Anemia of chronic inflammation/infection was the second most common etiology of anemia with 49 cases $(29.84 \%)$. Megaloblastic anemia, Dimorphic anemia, $\beta$ Thalassemia major, Sickle cell anemia \& Aplastic anemia (Fanconi's anemia) were seen in $6.81 \%, 10.80 \%, 16.48 \%, 1.14 \% \quad \& 1.14 \%$ cases respectively. (Table-3)

TABLE NO-3 ETIOLOGICAL \& MORPHOLOGICAL CLASSIFICATION OF 176 CASES OF ANEMIA:

\begin{tabular}{|l|l|l|l|l|l|l|l|}
\hline Sr No & Etiological /Morphological Type & NC/NC & NC/HC & Mic/HC & Mac/NC & Mac/HC & Total \\
\hline 1 & Nutritional anemia (53.4\%) & & & & & & \\
\hline a & Iron deficiency anemia (35.79\%) & & 14 & 49 & & & 63 \\
\hline b & Dimorphic anemia (10.80\%) & & & & & 19 & 19 \\
\hline c & Megaloblastic anemia (6.81\%) & & & & 12 & & 12 \\
\hline 2. & Anemia of Chronic inflammation/infection (27.84\%) & 34 & 09 & 06 & & & 49 \\
\hline 3. & $\begin{array}{l}\text { Hemolytic anemia (17.62\%) } \\
\text { Thalassemia (16.48\%) } \\
\text { Sickle cell anemia (1.14\%) }\end{array}$ & & & 29 & & & 29 \\
\hline 4. & Aplastic anemia (1.14\%) & & & & & 02 \\
\hline & Fanconi anemia (1.14\%) & 02 & & & & & 02 \\
\hline & Total & 38 & 23 & 84 & 12 & 19 & 176 \\
\hline
\end{tabular}

Weakness, easy fatiguability and irritability were the most common (82.39\%) presenting symptoms in the present study followed by loss of appetite \& weight with refusal of feeds $(75.57 \%)$. (Table-5)

TABLE NO.4: DISTRIBUTION OF 176 CASES AS PER PRESENTING SYMPTOMS
\begin{tabular}{|l|l|l|l|}
\hline Sr.No. & \multicolumn{1}{|c|}{ Presenting symptoms } & No of Cases & Percentage (\%) \\
\hline 1. & Weakness, easy fatiguability, irritability & 145 & $82.39 \%$ \\
\hline 2. & Loss of appetite and weight, refusal of feeds & 133 & $75.57 \%$ \\
\hline 3. & Fever & 110 & $62.50 \%$ \\
\hline 4. & Cough with or without expectoration & 97 & $55.11 \%$ \\
\hline 5. & Breathlessness and palpitations & 83 & $47.16 \%$ \\
\hline 6. & Pica & 52 & $29.55 \%$ \\
\hline 7. & Diarrhoea, vomiting & 29 & $16.48 \%$ \\
\hline 8. & Altered sensorium, convulsions & 2 & $1.14 \%$ \\
\hline
\end{tabular}

Pallor was the commonest sign noted in all cases (100\%) followed by tachycardia $(84.09 \%)$ (Table-5)

TABLE NO.5: DISTRIBUTION OF 176 CASES ACCORDING TO SIGNS OBSERVED

\begin{tabular}{|l|l|l|l|}
\hline Sr.No. & Signs & No of Cases & Percentage (\%) \\
\hline 1. & Pallor & 176 & $100 \%$ \\
\hline 2. & Tachycardia & 148 & $84.09 \%$ \\
\hline 3. & Signs of Malnutrition (Delayed mile stones, failure to thrive, decreased weight for age) & 142 & $80.68 \%$ \\
\hline 4. & Hemic murmur & 79 & $44.88 \%$ \\
\hline 5. & Edema & 42 & $23.87 \%$ \\
\hline 6. & Splenomegaly & 29 & $16.47 \%$ \\
\hline 7. & Features of hemolytic facies i.e. frontal bossing, malar prominence & 18 & $10.23 \%$ \\
\hline 8. & Hepatomegaly & 16 & $9.09 \%$ \\
\hline 9. & Lymphadenopathy & 12 & $6.81 \%$ \\
\hline 10. & Signs of meningeal irritation & 02 & $1.14 \%$ \\
\hline 11. & Features suggestive of Fanconi's anemia & 02 & $1.14 \%$ \\
\hline
\end{tabular}


Parin Upadhyay et.al. Clinicohematological profile of anemia in pediatric (newborn to eighteen years) age group.

TABLE NO,6: HB, MCV AND RDW VALUES IN IRON DEFICIENCY ANEMIA, ANEMIA OF CHRONIC INFECTION AND B THALASSEMIA MAJOR

\begin{tabular}{|l|l|l|l|l|}
\hline \multicolumn{2}{|c|}{ Type of Anemia } & Hb gm\% & MCV (fl) & RDW(\%) \\
\hline \multirow{2}{*}{ Iron deficiency Anemia } & Range & $4.5-11.8$ & $50.2-76.1$ & $13.3-28.4$ \\
\cline { 2 - 5 } & Mean & 8.9 & 64.1 & 17.6 \\
\hline \multirow{2}{*}{ Anemia of chronic infection } & Range & 3.5 to 11.3 & $70.5-85.9$ & $13.1-15.7$ \\
\cline { 2 - 5 } & Mean & 8.3 & 76.0 & 14.5 \\
\hline \multirow{2}{*}{$\beta$ Thalassemia Major } & Range & 2.7 to 10.1 & $52.8-78.5$ & 13.3 to 15.9 \\
\cline { 2 - 5 } & Mean & 6.54 & 64.4 & 14.6 \\
\hline
\end{tabular}

The mean values of $\mathrm{Hb}$ were reduced in all three types of anemia. The mean values of MCV were much reduced in Iron deficiency anemia followed by $\beta$ Thalassemia major and Anemia of chronic inflammation/infection. The mean RDW was strikingly raised in Iron deficiency anemia whereas near normal in Anemia of chronic inflammation/infection and $\beta$ Thalassemia Major

In cases of Iron deficiency anemia, the present study showed decreased values of $\mathrm{Hb}, \mathrm{MCV}, \mathrm{MCH}$ and $\mathrm{MCHC}$ and raised values of RDW compared to normal. In all cases of Iron deficiency anemia serum iron and serum ferritin levels were decreased while TIBC was raised.

In cases of Megaloblastic anemia, decrease in $\mathrm{Hb}$, TLC, RBC, Platelets \& Vitamin B12 values in all cases while MCV and RDW were raised in all cases.

\section{DISCUSSION}

Present study constituted 176 cases of anemia cases out of which $110(62.5 \%)$ cases were males and 66 cases (37.5) cases were females. Male: Female was 1.6:1. These results were in accordance with Sunil Gomber et $\mathrm{al}^{11}$, Abhishek Janjale et $\mathrm{al}^{12}$, Jasima et $\mathrm{al}^{13}$ who reported Male: Female as 1.15:1, 1.45:1 \& 1.7:1 respectively.

In the present study most common age group affected was 1-5 years age group with 54 cases $(30.68 \%)$. This study was comparable with study of Jasima et $\mathrm{al}^{13}$ who also reported maximum no of cases $(34 \%)$ in 1-5 years age group.

Moderate degree of anemia was most commonly seen in the present study with 78 cases $(44.32 \%)$. Similar observations were reported by Sharda Sidhu et $\mathrm{al}^{14}$.
In the present study Microcytic Hypochromic (47.73\%) was the most common morphological type followed by Normocytic Normochromic (21.59\%) anemia. Similar observations were made by Abhishek Janjale et $\mathrm{al}^{12}$, Prashant Marken et $\mathrm{al}^{15}$.

Abhishek Janjale et al $^{12}$ reported 47.76\% cases of Microcytic Hypochromic anemia followed by $28.81 \%$ cases of Normocytic Normochromic anemia. Prashant Marken et $\mathrm{al}^{18}$ reported $47.2 \%$ cases of Microcytic Hypochromic anemia followed by $36.0 \%$ cases of Normocytic Normochromic anemia.

Iron deficiency anemia with 63 cases $(35.79 \%)$ was the commonest type of anemia seen in the present study followed by anemia of chronic inflammation/ infection with 49 cases $(29.84 \%)$. This is in accordance with study done by Abhishek Janjale et $\mathrm{al}^{12}$ and Jasima et $\mathrm{al}^{13}$.

Present study reported more no of cases of respiratory tract inflammation/ infection $(55.10 \%)$ as a cause of anemia of chronic inflammation/infection followed by gastrointestinal inflammation/ infection (26.53\%) Similar observations were made by Abhishek Janjale et al $^{12}$ in his study reported $22.03 \%$ cases of respiratory tract inflammation/ infection followed by $6.78 \%$ of gastrointestinal tract inflammation/ infection.

Weakness, irritability and fatiguability were the most common presenting symptoms in 145 cases $(82.39 \%)$. Similar observations were made by Ramana Sastry C.P.V ${ }^{16}$ in his study who reported $81.8 \%$ cases presented with weakness.

Pallor was the commonest sign observed in all 176 cases (100\%). This is in accordance with studies done by Abhishek 
Janjale et $\mathrm{al}^{12}$, Ramana Sastry C.P.V ${ }^{16} \&$ Jasima et $\mathrm{al}^{13}$. All 3 studies also reported pallor as the most common sign observed in $100 \%$ cases.

In cases of Iron deficiency anemia, the present study showed decreased values of $\mathrm{Hb}, \mathrm{MCV}, \mathrm{MCH}$ and $\mathrm{MCHC}$ and raised values of RDW compared to normal. These values were in accordance with observations made by Ramana Sastry C.P.V ${ }^{16}$ \& Maheshwari B.K et al. ${ }^{17}$

In all cases of Iron deficiency anemia serum iron and serum ferritin levels were decreased while TIBC was raised. Similar observations were done by Ali et al ${ }^{18}$ in his study.

Present study reported 31 cases of Hemolytic anemia of which 29 cases were of $\beta$ Thalassemia major and 2 cases were of Sickle cell anemia. Present study reported maximum cases $(58.06 \%)$ of hemolytic anemias in 0-3 years age group. Shah Sejal et al 19 also reported maximum cases $(42.8 \%)$ in $0-3$ years age group. Male preponderance $(64.52 \%)$ was noted in 31 cases of Hemolytic anemias. Similar observations were made by Shah Sejal et al 19 with $74.3 \%$ male cases.

\section{CONCLUSION}

The present study underlines the importance of routine screening and individual assessment of etiological and risk factors of anemia in pediatric age group, allowing timely initiation of optimal and appropriate therapy which can prevent further complications of anemia. This also helps to break the vicious cycle of Anemia $\rightarrow$ increased susceptibility to infection $\rightarrow$ Chronic infection $\rightarrow$ Anemia \& failure to thrive in growing years of life.

\section{Acknowledgement: None}

\section{Conflict of Interest: None}

\section{Source of Funding: None}

Ethical Approval: Approved

\section{REFERENCES}

1. Bhargava M: Pediatric Hematology: A neglected speciality: Indian Paediatrics. Vol.19;1982:467-468.

2. Vinod K Paul \& Arvind Bagga.In: Ghai O.P: Essential Paediatrics. 9th edition.2019.

3. Lukens J.N: Iron metabolism and iron deficiency anemia. In: Denis \&Miller et al editors.Blood Diseases of Infancy and Childhood. 5th Edition; C.V Mosby;1984:115-146.

4. Rakesh Kumar Singh, Shraboni Patra, "Extent of anaemia among preschool children in EAG states, India. A challenge to policy makers," Anemia, vol.2014, 9 pages

5. Uttam Kumar Mondal, Pritikar Dowerah, Mukherjee R. Hemoglobinopathy in pediatric population:A cross sectional study at tertiary care center in Assam.Indian $\mathbf{J}$ Med Sci.2020.

6. Gupte S, Gupta RK, Gupta R. Iron Deficiency Anemia: A diagnostic approach in children. J K Science.2002;2:175-9.

7. Garder B. Anemias, of Inadequate Production. In: Kliegman RM, Behrman RE, Jenson H B, Stanton B F editors. Nelson Textbook of Pediatrics. 18th edition. Philadelphia, W.B. Saunders. 2008:2011-4.

8. CurrimbhoyZeenat. The value of Complete blood Count in Children. In: Parthasarathy A. IAP Textbook of Pediatrics .4th edition. Vol 1. New Delhi. JAYPEE. 2009:771-775.

9. Panigrahi A, Sahoo PB. Nutritional anemia and its epidemiological correlates among women women of reproductive in an urban slum of Bhubaneswar, Orissa. Indian $\mathbf{J}$ Public Health. 2011 (55):317-20.

10. Elaine M. Keohane, Larry J. Smith, Jeanine M. Walenga. Rodak's Hematology Clinical Principles And Applications. 5th edition: Elsevier Saunders;2016:1

11. Sunil Gomber, Bhawana, Nishi Madan. Prevalence and etiology of nutritional anemia among school children urban slums: Indian J Med Res, October 2003,118: 167171.

12. Abhishek Janjale, Sanket Pande et al. A Study of Severe Anemia in Children in a Tertiary Care Institute.MVP Journal of Medical Sciences. January-June 2018.Vol 5 (1),33-38.

13. F.K.K. Jasima Nilofer, Rajalakshmi V. Mary Lilly. Clinicohematological Study of Different Patterns of Anemia in Infancy and 
Parin Upadhyay et.al. Clinicohematological profile of anemia in pediatric (newborn to eighteen years) age group.

Childhood. Journal of Pharmaceutical Research International. April 2021.33 (20A):44-55,2021.

14. Sharada Sidhu, Kanta Kumari \& Manjula Uppal. Prevalence of anemia in Bazigar (Ex-nomadic Tribe) Preschool Children of Punjab. J Hum Ecol, 2007; 21(4): 265-267.

15. Prashant Marken, Vinay Bharat et al. Clinicohematological and Biochemical Profile of Anemia in Pediatric Age Group. International Journal of Research and Review. January 2020. 7(1):552-556.

16. Ramana Sastry C.P.V. Study on clinical and hematological profile of Anemia in children aged 5 to 12 years in rural Telangana. Pediatric Review. International Journal of Pediatric Research. July 2017.4(7).

17. Maheshwari BK, Raut P, Agarwal SK. A Study on the iron status in iron deficiency anemia one month before and after iron therapy in school going children: Journal of Clinical \& Diagnostic Research. April,2011; 5(2): 324-327.

18. Ali MA, Luxton AW, Walker WH. Serum ferritin concentration and bone marrow iron stores: a prospective study. Canadian Medical Association Journal. 1978;118 (8);945

19. Shah Sejal, Chauhan Sanjay, Rathod Hitesh: A profile of cases of hemoglobinopathies at a medical college. National Journal of Medical Research, 2012; 2:137-139.

How to cite this article: Upadhyay P, Kanetkar SR. Clinicohematological profile of anemia in pediatric (newborn to eighteen years) age group. Int J Health Sci Res. 2022; 12(2): 260-265. DOI: https://doi.org/10.52403/ijhsr.20220236 